\title{
The Determining of Relationship Between Physical Activity and Perceived Stress Level in Security Service Employees
}

\author{
Sema Can \\ Correspondence: Sema Can, Faculty of Sport Sciences, Hitit University, Çorum, Turkey. E-mail: semacan@ hitit.edu.tr
}

Received: November 7, 2018

Accepted: December 12, 2018 Online Published: December 25, 2018

doi:10.11114/jets.v7i1.3907

URL: https://doi.org/10.11114/jets.v7i1.3907

\begin{abstract}
The aim of this study is to determine physical activity (PA) levels and to analyze the relationship between PA and stress. 178 voluntary male $\left(\mathrm{M}_{\text {age: }} 33.01 \pm 4.70\right.$ year $)$ security employees participated in this study in total. The data were collected by self-report using the International Physical Activity Questionnaire (IPAQ)-Short Form and Perceived Stress Scale. Mean, standard deviation, frequency and percent values are given in the descriptive statistics of the variables. The relationship between physical activity and perceived stress level (PSL) was determined using the Spearman rho correlation. Mann-Whitney U-test was used to compare valuables. The Pearson Chi-Square test was used to examine the relationship between categorical variables and the significance level was set at 0.05 . The results show that $53.4 \%(n=95)$ of the individuals are physically inactive, $31.4 \%(\mathrm{n}=56)$ of them are minimally active, and only $15.2 \%(\mathrm{n}=27)$ are active. It was determined that approximately $1 / 4$ of the participants exercise regularly. Negative weak correlation appeared between moderate - vigorous physical activity (MVPA) and PSL $(r=-.221 ; \mathrm{p}<0.01) .78 .7 \%(\mathrm{n}=140)$ of the employees have moderate stress. Besides, $67.4 \%(n=29)$ of the individuals who work shifts and do PA regularly have moderate stress $(\mathrm{p}>0.05)$. On the other hand, $12.6 \%(\mathrm{n}=17)$ of the individuals who work shifts but do not do PA have high-stress $(\mathrm{p}<0.05)$. Individuals who state they do exercise regularly and work on a regular day shift have lower stress scores compared to those who do not $(\mathrm{p}<0.05)$. In conclusion, the research reveals that $3 / 4$ of the individuals have moderate stress and half of them are inactive. It can be said that less MVPA level and shift system is associated with a higher stress level. Joining physical activity programs regularly and increasing MVPA level can reduce perceived stress level.
\end{abstract}

Keywords: security employees, perceived stress level, physical activity

\section{Introduction}

Physically inactive lifestyle is one of the risk factors that negatively affect healthy and quality life. Age, gender, education, occupation, cultural, environmental, and social factors and lack of free time affects physical activity. (Owen et al., 2010; Sitthipornvorakul et al., 2014). In addition to this, intense usage of new technological advances and applications, and increasing demands (Lopes et al., 2010) might cause an increase in the prevalence of chronic disease, stress, and psychological problems (Dunstan et al., 2012; Martins and Lopes, 2013). 1.4 billion adults all over the world are reported to be inactive (WHO, 2018). To reduce inactivity, it is stated that at least 150 minutes (min) moderate, or at least 75 min intensity aerobic activity is vital for keeping healthy and quality life; in addition, it is important in fighting stress (WHO, 2010). People are under stress every day, be it low or high. The stress that profession causes on the employees occur because of the factors like difficulty of the work, workload, whether it is a deserved salary or not, fear of dismissal, providing direct service to people, an obligation of maintaining a specific weight (or BMI) or specific proper physical activity level (Birkök, 2004; Demirel, 2013). Security employees are in the service sector in Turkey and work within the scope of the law no. 5188, provide protection and safety in the public and private sector. In the service sector, especially in the security field, it is stated that stress and workload are very high (Bal, 2013). Employees of businesses offering security service face numerous inappropriate situation during their working hours and may be obliged to take initiative and make vital decisions. The risk of facing serious consequences of these decisions causes employees to be affected by psychological, emotional and physical stress like perpetually avoiding making mistakes (Bal, 2013). In the researches, it has been stated that work, long-term negative working conditions and lifestyle-related stress cause mental health problems and the most common and inevitable stress factor is "occupation" (Chopra, 2009; Lopes et al., 2010). It is stated that individuals who engage in regular physical activity could spend their lives less stressful than those who do not (Gimeno et al., 2009, Rod et al., 2009, O'Dougherty et al., 2012). Accordingly, the aim of this study is to determine PA levels of the security service employees who are at risk with regard to stress and inactivity and to examine the relationship between PA and stress. 


\section{Method}

\subsection{Participant (Subject) Characteristics}

This research was conducted on individuals providing security services working in public institutions and receive minimum wage in spring 2018. Data information form prepared by researcher (demographic information, weight, height, working hours, etc.) were used with IPAQ and stress scale. Partially filled surveys or by removing incorrect survey data, the data of 178 male employees have been evaluated. The study was approved by the local Ethics Committee, and Authorization was given by the ethics committee of Hitit University (2018/180).

\subsection{Data Collection Tool}

\section{International Physical Activity Questionnaire}

In order to examine the level of physical activity, the researchers applied a short version of the IPAQ. This allowed them to collect information about the frequency and duration of any physical effort (moderate and vigorous as well as walking) undertaken by the respondents in the previous week. On the basis of the values (expressed in MET-min/week) and after the standard calculations, physical activity levels were evaluated. The IPAQ sitting question is an additional indicator variable of time spent in sedentary activity and is not included as part of any summary score of physical activity. IPAQ-Short Form was developed by Craig et al. (2003), and the Turkish validity and reliability of IPAQ were made by Sağlam et al (2010). Besides, during the interview, data were gathered regarding age, height, body mass, working hours etc. of the respondents.

\subsection{Perceived Stress Scale}

Perceived stress scale is designed to measure the extent to which one perceived stress in a person's life. A fourteen-item version of the Cohen (1983) was used to assess perceived stress. Previously determined alpha coefficients of reliability for this instrument were $.84, .85$, and .86 (Cohen et al., 1983). "In the past 30 days, how often did you feel etc...? Response categories for each item included "never," "almost never," "sometimes," "fairly often," and "very often." To calculate a total level of perceived stress, seven items are reverse scored and then all are summed. For ease of interpretation, the score between 11 and 26 is low stress level, 27-41 is moderate stress level, 42-56 indicates high-stress level. Scale refers to total scores received from a person's stress level. Higher scores indicate higher levels of perceived stress. For use in Turkey validity and reliability studies were performed by Baltaş et al. (1998).

\subsection{Statistical Analysis}

Mean, standard deviation, frequency (f) and percent (\%) values are given in the descriptive statistics of the variables. Normality of the continuous variables was assessed by Shapiro-Wilk's test. For comparing variables, Mann-Whitney U-test was used. The relationship between physical activity and stress level was determined using the Spearman rho correlation. The Pearson Chi-Square test was used to examine the relationship between categorical variables. All the statistical analyses were performed using the SPSS package program (version 23.0), and the significance level was set at 0.05 for tests.

\section{Results}

The descriptive statistics of the study are given in Table 1.

Table 1. Descriptive statistics of the individuals

\begin{tabular}{cccc}
\hline $\mathbf{n : 1 7 8}$ & Mean \pm SD & Minimum & Maximum \\
\hline Age (year) & $33.01 \pm 4.70$ & 24 & 45 \\
Height $(\mathbf{c m})$ & $174.88 \pm 8.70$ & 165 & 197 \\
Weight $(\mathbf{k g})$ & $75.91 \pm 8.30$ & 65 & 120 \\
BMI $\left(\mathbf{k g} / \mathbf{m}^{2}\right)$ & $24.78 \pm 2.96$ & 23.50 & 35.10 \\
\hline
\end{tabular}

BMI: Body mass index; SD: Standard deviation 
The perceived stress and physical activity level of the individuals are given in Table 2 .

Table 2. Perceived stress level and physical activity level of the individuals.

\begin{tabular}{llccccc}
\hline Variables & & f & \% & Mean \pm SD & Minimum & Maximum \\
\hline & Low & 21 & 11.8 & & & \\
Stress level & Hoderate & 140 & 78.7 & $32.85 \pm 6.54$ & 18 & 48 \\
& & 17 & 9.5 & & & \\
MVPA (MET-min/week) & Yes & 131 & 73.6 & $1011.06 \pm 1385$ & 00 & 5760 \\
& No & 47 & 26.4 & & & \\
Walking (MET-min/week) & Yes & 97 & 54.5 & $1241.93 \pm 1909$ & 00 & 8316 \\
& No & 81 & 45.5 & & & \\
Total PA & Inactive & 95 & 53.4 & & & \\
(MET-min/week) & Minimally active & 56 & 31.4 & $1514.29 \pm 2280$ & 00 & 9918 \\
Sitting (min/day) & Active & 27 & 15.2 & & & \\
& & 178 & 100 & $152.85 \pm 202$ & 60 & 780 \\
\hline
\end{tabular}

MVPA: Moderate-vigorous physical activity; Min: Minute; SD: Standard deviation.

According to IPAQ for MVPA, it shows that $1011.06 \pm 1385$ MET-min/weeks. The results show that $53.4 \%(\mathrm{n}=95)$ of the individuals are physically inactive, $31.4 \%(\mathrm{n}=56)$ of them are minimally active, and only $15.2 \%(\mathrm{n}=27)$ of them are active. The perceived stress level was measured as $32.85 \pm 6.54$. The results show that $11.8 \%(\mathrm{n}=21)$ of the individuals have low stress, $78.7 \%(n=140)$ have moderate stress and only 9.5\% $(n=17)$ have high-stress (Table 2$)$.

The comparison of physical activity and working hours and stress scores of the participants are given in Table 3 .

Table 3. Comparison of physical activity and working hours and stress scores of the participants.

\begin{tabular}{lcccccc}
\hline Regular PA & Stress score & minimum & maximum & $\mathbf{U}$ & $\mathbf{Z}$ & $\mathbf{p}$ \\
\hline Yes $(\mathrm{n}=43)$ & $30.76 \pm 4.71$ & 23 & 40 & 2063.50 & -2.857 & $.001 *$ \\
No $(\mathrm{n}=135)$ & $33.73 \pm 6.78$ & 18 & 48 & & & \\
\hline Working hours & & & & & \\
\hline Daytime (n=36) & $29.00 \pm 4.67$ & 20 & 36 & 1367.00 & -4.314 & $.001 *$ \\
Shift (n=142) & $34.03 \pm 6.46$ & 18 & 48 & & &
\end{tabular}

*p<0.05; PA: Physical activity

It was determined that approximately $3 / 4$ of the participant had not been exercising regularly for the last one month. Stress scores of individuals who state that they do exercise regularly and have a regular day shift are lower than those who do not $(\mathrm{p}<0.05)$ (Table 3).

The relationship between regular physical activity, working hours, BMI and perceived stress level are given in Table 4 . Table 4. The relationship between regular physical activity, working hours, BMI and perceived stress level

\begin{tabular}{|c|c|c|c|c|c|c|}
\hline Regular PA & Working time & $\begin{array}{c}\text { Low stress } \\
\text { level }\end{array}$ & $\begin{array}{c}\text { Moderate stress } \\
\text { level }\end{array}$ & $\begin{array}{c}\text { High stress } \\
\text { level }\end{array}$ & Total & $\begin{array}{l}X^{2} \\
(\mathbf{p})\end{array}$ \\
\hline \multirow[t]{3}{*}{ Yes } & Daytime work & $0(0)$ & $8(18.6)$ & - & $8(18.6)$ & 1.594 \\
\hline & Shift & $6(14.0)$ & $29(67.4)$ & - & $35(81.4)$ & $(.207)$ \\
\hline & Total & $6(14.0)$ & $37(86.0)$ & - & $43(100.0)$ & \\
\hline \multirow{3}{*}{ No } & Daytime work & $6(4.4)$ & $22(16.3)$ & - & $28(20.7)$ & \multirow{3}{*}{$\begin{array}{c}7.857 \\
(.020)^{*}\end{array}$} \\
\hline & Shift & $9(6.7)$ & $81(60.0)$ & $17(12.6)$ & $107(79.3)$ & \\
\hline & Total & $15(11.1)$ & $103(76.3)$ & $17(12.6)$ & $135(100.0)$ & \\
\hline \multirow{4}{*}{$\underset{\left(\mathrm{kg} / \mathrm{m}^{2}\right)}{\mathrm{BMI}}$} & $18.5-24.9$ & $16(9.0)$ & $65(36.5)$ & $10(5.6)$ & $91(51.1)$ & \multirow{4}{*}{$\begin{array}{l}7.556 \\
(.109)\end{array}$} \\
\hline & $25.0-29.9$ & $5(2.8)$ & $70(39.3)$ & 7 (3.9) & $82(46.1)$ & \\
\hline & $30.0-35.0$ & $0(0)$ & $5(2.8)$ & $0(0)$ & $5(2.8)$ & \\
\hline & Total & $21(11.8)$ & $140(78.7)$ & $17(9.5)$ & $178(100)$ & \\
\hline
\end{tabular}

*p<0.05; BMI: Body mass index; PA: Physical activity

It was determined that $67.4 \%(\mathrm{n}=29)$ of the individuals who work shifts and do physical activity regularly have moderate stress $(\mathrm{p}>0.05) .12 .6 \%(\mathrm{n}=17)$ of the individuals who work shifts but do not do PA have high-stress $(\mathrm{p}<0.05)$ (Table 4). 
The correlations of between physical activity and perceived stress level parameters are given in Table 5 .

Table 5. The relationship between physical activity and perceived stress levels in the security employees

\begin{tabular}{ccccc}
\hline $\mathbf{n}=178$ & $\begin{array}{c}\text { MVPA } \\
(\text { MET-min/week }) \\
\mathbf{r}(\mathbf{p})\end{array}$ & $\begin{array}{c}\text { Walking } \\
\text { MET-min/week } \\
\mathbf{r}(\mathbf{p})\end{array}$ & $\begin{array}{c}\text { Sitting } \\
(\mathbf{m i n} / \mathbf{d a y}) \\
\mathbf{p}(\mathbf{r})\end{array}$ & $\begin{array}{c}\text { Total PA } \\
(\text { MET- min/week }) \\
\mathbf{r}(\mathbf{p})\end{array}$ \\
\hline $\begin{array}{c}\text { Perceived } \\
\text { stress level }\end{array}$ & $-.221 *(.003)$ & $.051(.496)$ & $-.170(.118)$ & $.026(.726)$ \\
\hline
\end{tabular}

${ }^{*} \mathrm{p}<0.01$; Min: minute; MET: Metabolic equivalent; MVPA: Moderate-vigorous physical activity.

A weak negative correlation was found between perceived stress scores and MVPA ( $p<0.01)$ (Table 5).

\section{Discussion}

Prevalent risk factors such as inactivity, morbidity, and resorting to advanced therapies cause an inevitable rise in health care spending (WHO, 2010). Most adults spend 1/3 of their free time sitting in their house, office and transportation (Owen et al., 2010; Lindström \& Rosvall 2018). According to WHO (2018), 1/4 of the adults physically inactive in the world. Governments (including Turkey) are concerned about this phenomenon and are striving to maintain the appropriate state of their citizens' health. In this study, the collected material indicates that $73.6 \%(\mathrm{n}=131)$ did MVPA, $54.5 \%(\mathrm{n}=97)$ did walking. In addition, according to IPAQ, 53.4\% $(\mathrm{n}=95)$ of the respondents are inactive, 31.4\% $(\mathrm{n}=56)$ are minimally active, and $15.2 \%(\mathrm{n}=27)$ are active. It has become clear that the level of physical activity of the respondents is not sufficient to remain healthy $(1514 \pm 2280$ MET-min/week)(Table2), and in this study, nearly 1/4 of the employees state that they do PA regularly. Navruz (2015), in point of physical activity score, of all that have been subjected to study, only $10 \%$ of the individuals' PA scores are "active enough" and $82.7 \%$ of them state that they do not do PA regularly. This corresponds to our study. Besides, it is shown that $11.8 \%(\mathrm{n}=21)$ low stress level, $78.7 \%(\mathrm{n}=140)$ moderate stress level, 9.5\% ( $\mathrm{n}=17)$ high-stress level (Table 2). In the studies conducted in different populations, (Akpınar, 2008; Günbayı and Tokel, 2012; Savcı and Aysan, 2014; Şanlı 2017), the fact that employee individuals have moderate stress level corresponds with our study results. Though it depends on occupation, stress is a natural result of professional life. As an individual's stress intensity and level rise, his/her work productivity may reduce. However, it is also impossible to avoid stress completely. Furthermore, it has been found that some stress factors has motivation-enhancing effects (McEwen, 2007). Therefore, it is noted that stress level must not drop below medium or optimal level (Baltaş and Baltaş, 2004). In this study, it has been seen that majority of the employees ( $\mathrm{n}=78.7 \%)$ have moderate stress (Table 2) Stress management, maintaining mental and physical health is necessary to sustain a productive life. However, stress must be managed very well in order to minimize its damages and to convert it into a motivating factor. Doing physical activity regularly is among the effective methods that reduce the negative effects of stress (Baltaş and Baltaş, 2004). In this study, it is seen that individuals ( $\mathrm{n}=43$ ) stating that they take part in PA regularly have lower stress scores $(\mathrm{p}<0.05$ ) (Table 3). In accordance with our study, Özylldırım (2015), states that employees who do physical activity regularly have a lower stress level. In many studies, the relationship between job stress and PA have been researched. It is shown that individuals that work under the challenging, negative and stressful conditions and experience job stress have a lower desire for participating in PA regularly, their activity levels reduce, and they quit PA (Kouvonen et al., 2005; Ok, 2006; Wijndaelea et al., 2007; Gimeno et al., 2009; Rod et al., 2009; Mäkinen et al., 2010; Martins and Lopes, 2013). Besides, it is noted that the inactivity of individuals who experience high-level psychological problems and stress is more possible (Muhsen et al., 2010; Martins and Lopes, 2013). Rod et al. (2009), emphasizes that stress reduces the time and energy that is necessary for PA. In the study, it is thought that factors such as being in the lowest income level group, working conditions, and the responsibility of the job can affect the stress level.

Salmon (2001) state that the stress and PA-exercise relationships are open to interpretation, and "people who are less disturbed by stress might simply be more ready to take up exercise training". But, Lutz et al. (2010) state that, it is valid only for those who follow a constant exercise program. In another study, Roemmich et al. (2003), states that changes in perceived stress are not associated with changes in exercise behavior $(r=-0.19)$. Existing evidence examining the relationship between PA and mental health has suggested that increased PA is associated with better mental health outcomes, such as mood, self-esteem, depression, stress, and anxiety (Dunn et al., 2001; Galper et al., 2006; Stults-Kolehmainen and Sinha, 2014). The intensity of exercise may play a key role as those who participated in an exercise that had a moderate intensity exhibited approximately half the amount of perceived stress as those who reported no exercise (Stults-Kolehmainen ve Sinha, 2014). In this study, negative weak correlation appeared between MVPA and PSL ( $r=-.221 ; \mathrm{p}<0.05)$. In accordance with study, Vankim and Nelson (2013), states that there is a negative correlation between vigorous PA level and perceived stress, and individuals that apply intense PA recommendations have less mental health complaint. Tomruk et al. (2016), notes that less physical activity level is associated with a 
higher level of perceived stress in physiotherapists. Koo and Kim (2018), for males with activity limitations, walking exercise had a positive effect on the perceived stress level. This result corresponds with a relationship between MVPA and stress in the study. Roemmich et al. (2003), state that acute and transient life stressors have a negative impact on PA in humans. Although it varies by gender, it is stated that there is a negative correlation between PA and birth of a new baby, a death of spouse, illnesses, working full time, starting a new job etc. especially in women (O'Dougherty et al., 2012; Stults-Kolehmainen and Sinha, 2014). Yet, Brown et al. (2009) state that some life events (a new relationship, retirement, changing working condition, great personal success etc.) is associated with increased PA. There are studies that have different/inconsistent results that show there is not a negative or positive correlation between stress and PA (Ali and Lindstrom, 2006; Roohafza et al., 2007; Phongsavan et al., 2008; Hansen et al., 2010; Goston et al., 2013). In general, the literature suggests that stress experiences affect physical activity. The relationship between PA and perceived stress may vary depending on factors such as gender, age, measurement method, sample size, and population. Because $80 \%$ of these factors are evidence of a relationship between PA and stress, one may think these factors have negative effects on stress (Stults-Kolehmainen ve Sinha, 2014). In this study, it is seen that shift workers have more stress scores (34.03 \pm 6.46$)$ than daytime workers $(29.00 \pm 4.67)(\mathrm{p}<0.05)$ (Table 3). Besides, in this study, it is determined that individuals who are shift workers and do not do PA $(\mathrm{n}=17 ; 12.6 \%)$ have high-level stress $(\mathrm{p}<0.05)$ (Table 4). Similar to study, Özyıldırım (2015) states that stress scores of employees increase according to the number of shifts. In the shift system, since the sleep and waking up times changes continuously, it can cause many physical and mental problems. Also, the fact that they cannot feel rested despite long sleep duration causes to reduce their life quality (Uzunbacak, 2017). In this study, 81.4\% ( $\mathrm{n}=35$ ) of the shift workers participated in the regular PA program and had low/moderate stress level (p>0.05) (Table 4). In this study, it can be said that regular PA is one of the important methods of fighting stress. Navruz (2015) stated that the number of individuals engaging in regular PA is higher in shift workers. This result is similar to our study. In addition, it is thought that more daytime hours allocated for PA in day-offs may affect the results.

\section{Limitations}

This study shows a general view of security employees' physical activity and perceived stress level. Limitations of study were small sample size and limited consideration of other factors associated with participation in physical activity levels. Further study should select an increased number of private security employees. About physical activity, since it is the first study on individuals working in security services in our country, it is important in contributing to the literature.

\section{Conclusion}

In our study, it is shown that approximately $3 / 4$ of the individuals have moderate stress and approximately $55 \%$ of them are inactive. The high-stress level is seen on the individuals working in a shift system and not engaging in PA regularly. Besides, it can be said that doing the less moderate-to-vigorous physical activity is associated with the high-stress level. Highlighting those physically active security employees reported better perceived stress might be a useful adjunct to encourage them to increase their physical activity and reduce stress with PA. Additionally, in this study, it should be taken into consideration that many factors associated with stress may have affected the results.

\section{References}

Akpınar, B. (2008). Opinions of teachers on the factors causing stress on teachers in the process of education. Kastamonu Education Journal, 16(2), 359-366.

Ali, S. M., \& Lindstrom, M. (2006). Psychosocial work conditions, unemployment, and leisure-time physical activity: a population-based study. Scand J Public Health, 34(2), 209-216. https://doi.org/10.1080/14034940500307515

Bal, V. (2013). Professional private security personnel working in the state of public satisfaction in manisa. $C B \ddot{U}$ Journal of Social Sciences, 11(1), 332-339.

Baltaş, A., \& Baltaş, Z. (2004). Stres ve başa çıkma yolları. İstanbul: Remzi Kitabevi.

Baltaş, Z., Atakuman, Y., \& Duman, Y. (1998). Standardization of the perceived stress scale: Perceived stress in Turkish middle managers. Stress and Anxiety Research Society, 19th International Conference: İstanbul.

Birkök, M. C. (2004). Poliste çatı̧̧ma ve stres yönetimi. Journal of Human Sciences, 1(1), 1-9. https://doi.org/10.14687/ijhs.v1i1.182

Brown, W. J., Heesch, K. C., \& Miller, Y. D. (2009). Life events and changing physical activity patterns in women at different life stages. Ann Behav Med, 37(3), 294-305. https://doi.org/10.1007/s12160-009-9099-2

Chopra, P. (2009). Mental health and the workplace: issues for developing countries. Int J Ment Heal Syst, 3(4).

Cohen, S., Kamarck, T., \& Melmerstein, R. (1983). A global measure of perceived stress. Journal of Health and Social Behavior, 24, 385-396. https://doi.org/10.2307/2136404. 
Craig, C. L., Marshall, A. L., Sjöström, M., Bauman, A. E., Booth, M. L., Ainsworth, B. E., .., Oja, P. (2003). International physical activity questionnaire: 12-country reliability and validity. Med Sci Sports Exerc, 35(8), 1381-1395.

Demirel, E. T. (2013). The effects of professional stress on job satisfaction: The mediating effect of organizational support. Omer Halisdemir University Academic Review of Economics and Administrative Sciences IIBBF Dergisi, 6(1), 220-241.

Dunn, A. L., Trivedi, M. H., \& O’Neal, H. A. (2001). Physical activity dose-response effects on outcomes of depression and anxiety. Med Sci Sports Exerc., 33, S587-S597. https://doi.org/10.1097/00005768-200106001-00027

Dunstan, D. W., Howard, B., Healy, G. N., \& Owen, N. (2012). Too much sitting--a health hazard. Diabetes Res Clin Pract, 97(3), 368-76.

Galper, D. I., Trivedi, M. H., Barlow, C. E., Dunn, A. L., \& Kampert, J. B. (2006). Inverse association between physical inactivity and mental health in men and women. Med. Sci. Sports Exerc., 38(1), 173-178. https://doi.org/10.1249/01.mss.0000180883.32116.28

Gimeno, D., Elovainio, M., Jokela, M., De Vogli, R., Marmot, M. G., \& Kivimäki, M. (2009). Association between passive jobs and low levels of leisure-time physical activity: the Whitehall II cohort study. Occup. Environ. Med., 66(11), 772-776. https://doi.org/10.1136/oem.2008.045104

Goston, J. L., Caiaffa, W. T., \& de Souza-Andrade, A. C., \& Vlahov, D. (2013). Health behaviors and occupational stress of Brazilian civil servants in an urban center. Am J Ind Med, 56(1), 49-57. https://doi.org/10.1002/ajim.22004

Günbayı, İ., \& Tokel, A. (2012). A comparative analysis of compulsory school teachers' job satisfaction and job stres levels. Social Sciences Research Journal, 3(5), 77-95.

Hansen, A. M., Blangsted, A. K., Hansen, E. A., Søgaard, K., \& Sjøgaard, G. (2010). Physical activity, job demand-control, perceived stress-energy, and salivary cortisol in white-collar workers. Int Arch Occup Environ Health, 83(2), 143-53. https://doi.org/10.1007/s00420-009-0440-7

Koo, K. M., \& Kim, C. J. (2018). The effect of the type of physical activity on the perceived stress level in people with activity limitations. Journal of Exercise Rehabilitation, 14(3), 361-366. https://doi.org/10.12965/jer.1836164.082

Kouvonen, A., Kivimaki, M., Elovainio, M., Virtanen, M., Linna, A., \& Vahtera, J. (2005). Job strain and leisure-time physical activity in female and male public sector employees. Prev Med, 41, 532-539. https://doi.org/10.1016/j.ypmed.2005.01.004

Lindström, M., \& Rosvall, M. (2018). Economic stress and low leisure-time physical activity: Two life course hypotheses. SSM Popul Health. 16(4), 358-364. https://doi.org/10.1016/j.ssmph.2018.04.005

Lopes, C. S., Araya, R., Werneck, G. L., Chor, D., \& Faerstein, E. (2010). Job strain and other work conditions: relationships with psychological distress among çivil servants in Rio de Janeiro, Brazil. Soc Psychiatry Psychiatr Epidemiol, 45, 345-354. https://doi.org/10.1007/s00127-009-0066-9

Lutz, R. S., Stults-Kolehmainen, M. A., \& Bartholomew, J. B. (2010). Exercise caution when stressed: stages of change and the stress-exercise participation relationship. Psychol Sport Exerc, 11(6), 560-567. https://doi.org/10.1016/j.psychsport.2010.06.005

Mäkinen, T., Kestilä, L., Borodulin, K., Martelin, T., Rahkonen, O., Leino-Arjas, P., \& Prättälä, R. (2010). Occupational class differences in leisure-time physical inactivity-contribution of past and current physical workload and other working conditions. Scand J Work Environ Health, 36, 62-70. https://doi.org/10.5271/sjweh.2879

Martins, L. C. X., \& Lopes, C. S. (2013). Rank, job stress, psychological distress and physical activity among military personnel. BMC Public Health, 13, 716. https://doi.org/10.1186/1471-2458-13-716

McEwen, B. S. (2007). Physiology and neurobiology of stress and adaptation: central role of the brain. Physiol Rev, 87(3), 873-904. https://doi.org/10.1152/physrev.00041.2006

Muhsen, K., Garty-Sandalon, N., Gross, R., \& Green, M. S. (2010). Psychological distress is independently associated with physical inactivity in Israeli adults. Prev Med, 50(3), 118-122. https://doi.org/10.1016/j.ypmed.2009.12.002

Navruz, S. (2015). A study on the assessment of the prevalence of metabolic syndrome among healthcare shift workers. Gazi University Institute of Health Sciences. (M. Sc. Thesis).

O'Dougherty, M., Hearst, M. O., Syed, M., Kurzer, M. S., \& Schmitz, K. H. (2012). Life events, perceived stress and depressive symptoms in a physical activity intervention with young adult women. Ment Health Phys Act, 5(2), 148-154. 
Ok, İ. (2006). İş stresinin ilköğretim okullarında okul yöneticileri üzerindeki etkisi (Konya Örneği). Selçuk Üniversitesi Sosyal Bilimler Enstitüsü Eğitim Bilimleri Anabilim Dalı. (YL tezi)

Owen, N., Sparling, P. B., Healy, G. N., Dunstan, D. W., \& Matthews, C. E. (2010). Sedentary behavior: Emerging evidence for a new health risk. Mayo Clinic Proceedings, 85(12), 1138-1141. https://doi.org/10.4065/mcp.2010.0444

Özyıldırım, E. (2015). Quality of life, perceived stress level and investigation the factors affecting among the physicians' working in Erzurum province. Atatürk University Faculty of Medicine Department of Public Health (M. Sc. Thesis).

Phongsavan, P., Merom, D., Wagner, R., Chey, T., von Hofe, B., Silove, D., \& Bauman, A. (2008). Process evaluation in an intervention designed to promote physical activity among adults with anxiety disorders: evidence of acceptability and adherence. Health Promot J Austr, 19(2), 137-143. https://doi.org/10.1071/HE08137

Rod, N. H., Gronbaek, M., Schnohr, P., Prescott, E., \& Kristensen, T. S. (2009). Perceived stress as a risk factor for changes in health behaviour and cardiac risk profile: a longitudinal study. J Intern Med, 266, 467-475. https://doi.org/10.1111/j.1365-2796.2009.02124.x

Roemmich, J. N., Gurgol, C. M., \& Epstein, L. H. (2003). Influence of an interpersonal laboratory stressor on youths' choice to be physically active. Obes Res, 11(9), 1080-1087. https://doi.org/10.1038/oby.2003.148

Roohafza, H., Sadeghi, M., Sarraf-Zadegan, N., Baghaei, A., Kelishadi, R., Mahvash, M. M. S.,... Talaei, M. (2007). Short communication: relation between stress and other life style factors. Stress Health, 23(1), 23-29. https://doi.org/10.1002/smi.1113

Sağlam, M., Arıkan, H., Savcı, S., İnal-İnce, D., Bosnak-Güçlü, M., Karabulut, E., \& Tokgözoğlu, L. (2010). International physical activity questionnaire: reliability and validity of the Turkish version. Percept Mot Skills, 111, 278-284. https://doi.org/10.2466/06.08.PMS.111.4.278-284

Salmon, P. (2001). Effects of physical exercise on anxiety, depression, and sensitivity to stress: a unifying theory. Clin Psychol Rev, 21(1), 33-61. https://doi.org/10.1016/S0272-7358(99)00032-X

Şanl1, O. (2017). Analysing the perceived stress level of teachers with regards to some variables. Electronic Journal of Social Sciences. 16(61), 385-396.

Savc1, M., \& Aysan, F. (2014). The relationship between the perceived stress level and the stress coping strategies in university students. International Journal of Turkish Education Sciences, 10, 44-56.

Sitthipornvorakul, E., Janwantanakul, P., \& J van der Beek, A. (2014) Correlation between pedometer and the global physical activity questionnaire on physical activity measurement in office workers. BMC Res Notes, 7, 280.

Stults-Kolehmainen, M. A., \& Sinha, R. (2014). The effects of stress on physical activity and exercise. Sports Med, 44(1), 81-121. https://doi.org/10.1007/s40279-013-0090-5

Tomruk, M. S., Gurpınar, B., Ozyurek, S., Karadibak, D., Cakır, O., \& Angın, S. (2016). Relationship between physical activity and perceived stress in physiotherapists. Journal of Exercise Therapy and Rehabilitation, 3(1), 15-20.

Uzunbacak, H. (2017). A qualitative research about the effects of working hours on quality of family life. Hitit University Journal of Social Sciences Institute, 2, 1235-1256. https://doi.org/10.17218/hititsosbil.319719

VanKim, N. A., \& Nelson, T. F. (2013). Vigorous physical activity, mental health, perceived stress, and socializing among college students. Am J Health Promot, 28(1), 7-15. https://doi.org/10.4278/ajhp.111101-QUAN-395

World Health Organization. (2018). http://www.who.int/ncds/prevention/physical-activity/lancet-global-health-insufficient-physical-activity-2001-2016 /en/. Accessed: 20.10.2018.

Wijndaelea, K., Mattonb, L., Duvigneaudc, N., Lefevreb, J., De Bourdeaudhuija, I., Duquetc, W., ... Philippaerts, R. M. (2007). Association between leisure time physical activity and stress, social support and coping: a clusteranalytical approach. Psychol Sport Exerc, 8, 425-440. https://doi.org/10.1016/j.psychsport.2006.08.001

World Health Organization. (2010). Global recommendations on physical activity for health. Geneva.

\section{Copyrights}

Copyright for this article is retained by the author(s), with first publication rights granted to the journal.

This is an open-access article distributed under the terms and conditions of the Creative Commons Attribution license which permits unrestricted use, distribution, and reproduction in any medium, provided the original work is properly cited. 